\title{
AN UNDERGROUND MEDICAL SCHOOL IN THE WARSAW GHETTO, 1941-2
}

\author{
by \\ CHARLES G. ROLAND *
}

\begin{abstract}
There is within us some hidden power, mysterious and secret, which keeps us going, keeps us alive, despite the natural law. If we cannot live on what is permitted, we live on what is forbidden.
\end{abstract}

Chaim Kaplan, 10 March 1940, Warsaw ${ }^{1}$

The Holocaust-the deliberate destruction of most of the Jews and Gypsies of Europe along with enormous numbers of the non-Jewish population of eastern Europe-is arguably the least understandable event since the Creation. Reactions to the Holocaust by those who were enmeshed in it are, however, more comprehensible. A very few committed suicide; ${ }^{2}$ some became totally involved in self-preservation at all costs; many tried to ignore the grim reality and avoided facing up to its implications; most behaved decently and even nobly as the situation deteriorated. One inspirational reaction of Polish Jews was the creation and operation of a medical school within the Warsaw ghetto, modelled on standard European curricular lines, though with appropriate adaptations to accommodate unique circumstances. Its intent was to educate Jewish youth in medicine and, if the situation permitted and the war lasted that long, to qualify physicians to fill the depleted ranks of the Jewish medical profession in Warsaw. The founders thus intended the school to express their belief that they still maintained some control over their lives and their futures.

With the conventional wisdom of hindsight we can perceive the impossibility of the task. The odds can scarcely have seemed much better to those who established the school. Against those odds, it operated for 15 months, most of two academic years. Only a few students survived. Some became physicians and a very few are still practising medicine, almost 50 years after the school was submerged in the chaos attending the eradication of the ghetto and its inhabitants.

This paper is an effort to tell the story of the underground medical school using, wherever possible, eyewitness testimony.

\section{THE SURVIVOR-INTER VIEWEES}

By coincidence only, the survivors whom I have interviewed provide a reasonably

\footnotetext{
*Charles G. Roland, MD, Jason A. Hannah Professor of the History of Medicine, McMaster University, Hamilton, Ontario L8N 3Z5, Canada.

1 'Extracts from the Warsaw ghetto diary of Chaim A. Kaplan, 1940', in Y. Arad, Y. Gutman, and A. Margaliot, Documents on the Holocaust, New York, Ktav Publishing House, 1982, p. 202.

${ }^{2}$ Suicide among German Jews has been analysed by Konrad Kwiet, 'The ultimate refuge: suicide in the Jewish community under the Nazis', Leo Baeck Inst. Yb., 1984, 29: 135-67.
} 


\section{Charles G. Roland}

representative cross-section of the medical school. There is one teacher from amongst the department heads identified in the Appendix-Dr Ludwik Stabholz, Department of Anatomy-and one teacher from the faculty at large-Dr Henry Fenigstein. ${ }^{3}$

The other interviewees were students in 1941-2. In the short life of the school, many young men and women began their studies but, for various reasons, did not continue. One of these was Eugenia Pernal, who became a nurse instead. Four more interviewees began their medical training in the clandestine school: Karolina Borman, who completed her medical education in Poland after the war, emigrated, and practised medicine in the United States until her death in 1987; Irena Bakowska, her sister, who became a lawyer after 1945 ; Halina Berg, ${ }^{4}$ who trained in pharmacy in post-war Poland and practices that profession there still; and B. J. Wygodzka, ${ }^{5}$ a doctor in Poland today. The other two interviewees come from the group of students who had begun medical training before the war and who continued that education in the ghetto; they are Tadeusz Stabholz (cousin of Ludwik Stabholz, the anatomist), who had been attending the medical school at the University of Warsaw from 1937 on, and Marek Balin, who had studied at the Sorbonne, in Paris, also since 1937. Both completed their medical education after the war, emigrated to the United States, and still live there.

In addition, there is Millie Eisen, who was a nurse in the Czyste Hospital from 1938 until she escaped from the ghetto. Both she and Eugenia Pernal have provided helpful observations on the state of the hospitals within which the students were expected to learn their profession. Four of these survivors made their post-war homes in the United States, three in Canada, one in Israel, and two remained in Poland.

\section{POLITICAL AND MILITARY BACKGROUND}

Less than a month after their invasion, the armed forces of Nazi Germany compelled the capitulation of Poland. In Warsaw, hostilities ceased on 27 September 1939. ${ }^{6}$ Repression of the population, especially of the Jews, began immediately. On 4 October, the Judenrat was created by the Germans to replace the Kehilla. The latter had been a religious and social institution of the type that existed in every Jewish community; the Judenrat, however, was a political and economic bureaucracy intended by the Germans to continue the activities of the Kehilla and, in addition, to be a means to force the Jewish community not only to carry out German orders but also to pay for their enforcement. ${ }^{7}$ The multiple duties imposed on the Judenrat were those

\footnotetext{
${ }^{3}$ Although not listed on the announcement, Dr Fenigstein's position is documented in contemporary sources; Jerusalem, Yad Vashem Archives (hereafter, YVA) 03/2358, report by Dr Stanislaw Waller, p. 9: "Anatomje patologiczna prowadzil dyr. STEIN, a faktycznie dr. GILDE i dr. FENICSZEJN [sic]."

${ }^{4}$ At the request of this interviewee, a pseudonym is used here. Of the few Jews remaining in Poland today, many have hidden their heritage for purposes of survival. Any reader believing this precaution to be unnecessary might note the following, about a Polish citizen interviewed in connection with a book on Sobibor: "His co-workers had recently blackmailed him into an early retirement from his sensitive government job after they discovered he was a Jew." (Richard Rashke, Escape from Sobibor, New York, Avon Books, 1987, p. 337.)

${ }^{5}$ At the request of this interviewee, a pseudonym is used here.

${ }^{6}$ Robert M. Kennedy, The German campaign in Poland, (1939), Washington, Department of the Army, 1956, p. 113.

${ }^{7}$ Jacob Apenszlak (ed.), The black book of Polish Jewry: an account of the martyrdom of Polish Jewry under the Nazi occupation, New York, Howard Fertig, 1982, pp. $222 \mathrm{ff}$.
} 
associated with a municipality, including public health, police, distribution of supplies, postal services, and employment. ${ }^{8}$ Even as they demanded that the Judenrat undertake these responsibilities, the Germans ensured its ultimate failure by supplying, or permitting to be supplied, too little of everything.

On 23 November 1939, a decree ordered every Jew in Warsaw to wear a white armband bearing a blue Star of David, on the right sleeve below the elbow. ${ }^{9}$ One of its immediate effects was to further inflame a violently anti-Semitic element of the Polish population by identifying prospective subjects for humiliation, robbery, and injury. Economic sanctions, forced labour, and indiscriminate confiscation of property, as well as beatings, rape, ${ }^{10}$ and murder-carried out by Polish rowdies, Ukrainian- and other nationals in German service, and Germans themselves-became part of the routine of life for Warsaw's Jews from 1939 onwards.

On 4 November 1939, the victorious Germans first revealed their intention to create a ghetto. In a revealing insight on the lack of cohesion amongst the German conquerors, the order was issued by the SS in the name of the Wehrmacht military commander of the city. The latter knew nothing of the order, which was set aside. ${ }^{11}$ However, the idea was retained and planning proceeded. By March 1940, the Nazi rationale was centred on their stated conviction that the Jews were especially susceptible to typhus and must therefore be confined in order to prevent the spread of this much-feared disease. ${ }^{12}$ However, on 8 March the plan was postponed yet again. ${ }^{13}$ Even so, on 1 April 1940, Jews were forced to begin digging ditches in preparation for the construction of walls. ${ }^{14}$

The German Governor of the Warsaw District, Dr Ludwik Fischer, issued an order on 2 October establishing the boundaries of the ghetto and calling for its institution by 31 October. ${ }^{15}$ This date was changed twice, but by 15 November 1940 the ghetto existed. About 80,000 Christian Poles had been moved out of the area and around

\footnotetext{
${ }^{8}$ Dawidowicz has emphasized the Judenrat's vastly expanded area of responsibility compared to the Kehilla. The latter was a "Gemeinschaft" institution, whereas the former was forced to become a "Gesellschaft" institution, i.e., one devoted to providing crucial services, without the necessary funding. Lucy S. Dawidowicz, The war against the Jews, 1939-1945, Toronto, Bantam Books, 1986, p. 229. The topic of the Judenrat has been explored extensively in Isaiah Trunk, Judenrat: the Jewish councils in eastern Europe under Nazi occupation, New York, Macmillan, 1972.

9 [Anon.], The German new order in Poland, London, Hutchinson, [1942].

10 Officially, German citizens were forbidden to have sexual relations with Jews because of a supposed danger of "race defilement". See Helen Fein, Accounting for genocide: national responses and Jewish victimization during the holocaust, University of Chicago Press, 1984, p. 21. In fact, opportunity often overrode edict, especially before the Jews were effectively isolated from the rest of Warsaw within the walled ghetto. See Apenszlak, op. cit., note 7 above, pp. 28-9. It seems well established that Jewish girls and women were demanded by the Nazis for service in brothels intended for German soldiers stationed in Warsaw; see the affidavit of Dr Henryk Szoszkies, 14 January 1940, published in ibid., pp. 26-8.

11 Yisrael Gutman, The Jews of Warsaw, 1939-1943: ghetto, underground, revolt, trans. Ina Friedman, Bloomington, Indiana University Press, 1982, pp. 48-50.

${ }^{12}$ Christopher R. Browning, 'Nazi ghettoization policy in Poland: 1939-41', Cent. Eur. Hist., 1986, 19: 343-68; Gutman, op. cit., note 11 above, p. 50.

${ }^{13}$ Waldemar Schon, cited in Arad et al., op. cit., note 1 above, p. 223.

${ }^{14}$ R. Hilberg, S. Staron, and J. Kermisz (ed.), The Warsaw diary of Adam Czerniakow: prelude to doom, New York, Stein and Day, 1982, p. 135.

${ }^{15}$ Schon, in Arad et al., op. cit., note 1 above, pp. 221-2.
} 
140,000 Jews forced in. ${ }^{16}$ The underground medical school was a product of this ghettoized phase of Jewish life in Warsaw. ${ }^{17}$

\section{EDUCATION IN POLAND AND IN WARSAW}

Throughout Poland, education ground to a halt under German rule. ${ }^{18}$ The aim of this policy, for Christian Poles, was to permit only semi-literacy, sufficient for what was intended to be a population of manual labourers. ${ }^{19}$ The Jews were scheduled for relocation or, later on, extinction, and thus their education required no planning on any long-term basis. In Warsaw, the last Jewish school closed its doors on 4 December 1939.20

Initially, teaching was forbidden at every level within the Jewish population, although some elementary schools eventually were permitted to open. The other exception was to be crucial to the establishment of the underground medical school: as was the case outside the ghetto, a few technical or trade schools were opened under German authority. On 31 August 1940, Hans Frank, Governor General of the Nazi Generalgouvernement, ${ }^{21}$ issued a decree authorizing the Judenrat to provide elementary and vocational schools for the Jewish population. ${ }^{22}$ Word of the new policy reached the ghetto even before this date, for Adam Czerniakow, Chairman of the Warsaw Judenrat, noted in his diary for 18 August that permission had been granted "to conduct some vocational courses"; on the 19th he named the members of the vocational education commission; and on 21 August he noted with evident pride, "In the course of three days we have started our vocational courses." 23 Although it did not

${ }^{16}$ Helen Fein, Accounting for genocide, New York, The Free Press, 1979, p. 221.

17 The planning and implementation of the Warsaw ghetto has been described extensively. Useful sources include Joseph Kermish (ed.), To live with honor and die with honor: selected documents from the Warsaw ghetto underground archives, "O.S." (Oneg Shabbath), Jerusalem, Yad Vashem, 1986; and Gutman, op. cit., note 11 above.

18 The clandestine education of Poles, Christian was well as Jewish, was carried on with vigour in many centres during the years of Nazi occupation. Medical studies of many levels of complexity and sophistication were pursued in Edinburgh, by escaped Polish students, and in many cities within Poland. This work has been summarized by Witold Rudowski and Ryszard Zablotniak, 'Clandestine medical studies in Poland, 1939-1945', J. roy. Coll. Surg. Edinb., 1978, 23: 239-52. According to these authors, there were at least seven different medical schools or courses in Warsaw at different times, many of these being incorporated into the Jan Zaorski School, which began in March 1941, and which had a total of about 1,900 students; the Zweibaum school in the ghetto, with about 500 students, was the next largest; of course, the ghetto school operated for only 14 months, whereas the non-Jewish school lasted several years. See also Leonard J. Bruce-Chwatt and Zbigniew Bankowski, 'An unknown page in the history of medicine', J. Am. Med. Ass., 1967, 201: 946-8, regarding the Zaorski school. Some of those students fortunate enough to escape from the Nazi orbit continued their medical education in Scotland; see J. Rostowski, History of the Polish School of Medicine, University of Edinburgh, University of Edinburgh, 1955.

${ }^{19}$ For example, in the Polish schools that were permitted to function outside the ghetto, “. . . teachers and pupils had to pretend they were engaged upon a simple grammar lesson, or the like, when German inspectors entered the classroom." Z. Stypulkowski, Invitation to Moscow, London, Thames and Hudson, 1951, p. 51.

${ }^{20}$ Louis Falstein (ed.), The martyrdom of Jewish physicians in Poland, New York, Exposition Press, 1963, p. 177.

21 The Government General, German-occupied Poland, which was administered by a civilian German governor headquartered in Cracow.

22 Dawidowicz, op. cit., note 8 above, p. 253.

${ }^{23}$ Hilberg et al., op. cit., note 14 above, pp. 186, 188. 
begin operation for some months, the course of importance to this study was one designed to train personnel needed to fight epidemics.

\section{MEDICAL CONDITIONS IN THE GHETTO}

Of epidemics there was no end. The Germans forced between 400,000 and 500,000 Jews to live inside the ghetto, in a space of less than 1,000 acres, so that over 30 per cent of the population of Warsaw was living in 5 per cent of its area. ${ }^{24}$ One of the reasons used by the Germans to justify establishing the ghetto was the existence of epidemics, particularly of typhus, among the Jews. ${ }^{25}$ Although there is little evidence that substantial epidemics took place before the ghetto was created, and no evidence that Jews were any more likely to suffer from, or transmit, typhus than anyone else, by setting up the ghetto and forcing so many people to live there, the Germans made their contention self-fulfilling: typhus did indeed ravage the Jews of the Warsaw ghetto.

By August of 1941, the chief historian in the ghetto was observing that: "Next to hunger, typhus is the question that is most generally absorbing for the Jewish populace . . . . The graph line of typhus cases keeps climbing." ${ }^{26}$ At this time there were, on any day, about 900 typhus patients in hospital and more than 6,000 ill at home. Monthly mortality rates had risen from 900 in January 1941 , to more than 5,500 in August. ${ }^{27}$ And these figures represent only reported cases; for a variety of reasons, the existence of typhus was often hidden. ${ }^{28}$ The water supply was reduced progressively by the Germans and, as more and more penniless refugees from other parts of Poland and occupied Europe were forced into the ghetto, proper sanitation became impossible. Lice were ubiquitous. Not even the well-to-do could escape them; one interviewee described, with amusement now, how her parents purchased silk underwear for her, on the premise that lice would find the material too slippery and would not attach themselves. ${ }^{29}$ No preventative measures seemed to work, ${ }^{30}$ or were available in sufficient volume to work.

In addition to the high incidence of disease, hunger was the characteristic problem

\footnotetext{
${ }^{24}$ Schon, cited in Arad et al., op. cit., note 1 above, p. 227; Donat gives the figures as $37 \%$ of the population in an area equalling $4.6 \%$ of Greater Warsaw (Alexander Donat, The Holocaust kingdom: a memoir, New York, Holocaust Library, 1978, p. 35).

${ }^{25}$ According to Schon, who was Head of the Department of Resettlement in the Warsaw District, "The German Army and population must in any case be protected against the Jews, the immune carriers of the bacteria of epidemics." Cited in Arad et al., op. cit., note 1 above, p. 225.

${ }^{26}$ Jacob Sloan (ed. and trans.), Notes from the Warsaw ghetto: the journal of Emmanuel Ringelblum, New York, Schochen Books, 1974, p. 194.

${ }^{27}$ Arad et al., op. cit., note 1 above, p. 245.

${ }^{28}$ McMaster University, Hannah Chair in the History of Medicine, Oral History Archives (hereafter HCMU/OHA), interview of Eugenia Pernal by Charles Roland, HCM 4-87, 19 May 1987, pp. 8, 13. All interviews identified by the acronym HCM (Hannah Chair, McMaster) were conducted by Charles G. Roland; that fact will not be noted hereafter. See also Fein, op. cit., note 16 above, p. 228.

${ }^{29}$ HCMU/OHA, interview of Karolina Borman, HCM 23-82, 26 Sept. 1982, p. 10.

30 Adam Czerniakow recorded, as early as April 1940, a racket that was voiding the potential utility of disinfection centres. "A new industry: a woman who, for money, will take the place of another person at a disinfection steambath." Hilberg et al., op. cit., note 14 above, p. 140. However, Hirszfeld believed that the methods used to bypass disinfection procedures actually saved lives, because the "preventive medicine" prescribed by the Nazis would have been lethal if followed according to instructions; Ludwik Hirszfeld, 'The story of one life', op. cit., note 135 below, pp. 218-21.
} 


\section{Charles G. Roland}

of the ghetto. Indeed, hunger was the fundamental problem, one that almost every Jew struggled with at length. From 1940, large numbers of Jews began to starve to death; after the ghetto was walled in, the pace accelerated.

So widespread was hunger that it became the subject of a major, if clandestine, scientific study by the medical profession within the ghetto, on the practical principle that starvation was the one thing that they had in unfailing abundance. ${ }^{31}$ The findings of work done by many scientists and physicians were smuggled out of the ghetto and hidden by sympathetic colleagues until after the war, when they were published in French, ${ }^{32}$ Polish, ${ }^{33}$ and recently in a condensed version in English. ${ }^{34}$ Many of the contributors were also members of the faculty of the underground school. For the majority, it was the last scientific work they would undertake.

In mid-1941, an observer estimated that of the half-million Jews in the Warsaw ghetto, half could be classified as being poor enough to need social aid, though the available food permitted the community to serve only 120,000 soup rations a day. ${ }^{35} \mathrm{~A}$ worker's daily ration a year later was a quarter of a loaf of bread plus some watery cabbage soup; "Who can be spurred to work with this kind of food?"36 An unidentified inhabitant of the ghetto recorded seeing a boy sweep something up out of the dirt of the street, and eat it; some ersatz coffee made of roasted wheat was mixed in the mud. ${ }^{37}$ But nothing describes more nauseatingly the state of many of Warsaw's Jews than the incident of a girl walking to the doctor's office with a jar containing a specimen of her sick mother's faeces; the jar was snatched from her on the street and the contents gulped down by a starving man. ${ }^{38}$

Even in the hospitals, no respite was possible. The food ration authorized by the Germans for each patient was estimated by an internist there as supplying, at the most, 800 calories daily. Death from starvation was "as common in the hospital as in the street or at home". 39

Throughout the ghetto, efforts were made to feed the hungry. House collectives tried to provide food for the poor amongst them, charitable and political groups established kitchens, orphanages, and children's shelters, and various other centres arose. ${ }^{40}$ One

\footnotetext{
31 "Because of the unique population that was available for study, observations could be made which had never been made before and some of which have never been made since." Myron Winick, "Preface", in Myron Winick (ed.), Hunger disease: studies by the Jewish physicians in the Warsaw ghetto, trans. Martha Osnos, New York, John Wiley \& Sons, 1979, p. ix; an earlier book described the project and summarized its findings: Leonard Tushnet, The uses of adversity, New York, Thomas Yoseloff, 1966, p. 108.

32 Emil Apfelbaum (ed.), Maladie de famine: recherches cliniques sur la famine exécutées dans la ghetto de Varsovie en 1942, Warsaw, American Joint Distribution Committee, 1946.

${ }^{33}$ Idem (ed.), Choroba glodowa: badania kliniczne nad glodem wykonane w getcie Warszawskim z roku 1942, Warsaw, American Joint Distribution Committee, 1946.

${ }^{34}$ Winick, op. cit., note 31 above.

35 [Anon.], 'The Jewish Quarter in Warsaw', in Kermish, op. cit., note 17 above, p. 146.

${ }^{36}$ [Peretz Opoczynski], 'Warsaw Ghetto chronicle-September 1942', entry for 14 September, in ibid., p. 107.

37 [Anon.], 'Snapshot from the Warsaw Ghetto', 21 April 1941, in ibid., p. 78.

38 YVA, 033/1558 E 104-4-7, testimony of Dr Emil Apfelbaum, former head of the Department of Medicine, Czyste Hospital, p. 5. (Statement recorded in the summer of 1945; translated by Martha and Robert Osnos.)

39 YVA 033/1558 E 104-4-7, Apfelbaum, p. 7.

${ }^{40}$ For a synoptic account of many of these efforts, see 'The profile of the Jewish child', in Kermish, op. cit., note 17 above, pp. 371-91.
} 


\section{A medical school in the Warsaw ghetto}

interviewee remembers her mother stretching the noon meal, the main meal of the day, which was only soup, farther and farther. Neighbours and others who had no food were invited in, so more water was added. ${ }^{41}$ But the need far exceeded the means that could be found, not only privately but also in the community. As Adler observed, "Natural death in the street from hunger, exhaustion, exposure, heart attack, or infectious disease had become the rule."42

\section{ECONOMICS}

Neither the Warsaw ghetto nor the underground medical school was exempt from the economics of oppression: theft, blackmail, extortion, and chicanery were the operative techiques. Individual Germans from the highest official to the humblest soldier seemed determined to make the most of the financial opportunities that presented themselves. Extortion was commonplace. To give a single example, a large group of refugees was confined in the quarantine station just outside the Warsaw ghetto. The manager expressed "regret" that he must obey the rules and force them to remain in the unhygienic building for the full fourteen days. After negotiation, for 10,000 zlotys $^{43}$ the group moved on into the ghetto after a single painful winter night during which the temperature fell to $-25 \mathrm{C}^{\circ}\left(-15 \mathrm{~F}^{\circ}\right) .^{44}$

No Jew was permitted to have more than $2,000 \mathrm{zl}$ in cash, and all other funds had to be deposited in a bank designated by the Germans, from which one could withdraw no more than $500 \mathrm{zl}$ monthly. ${ }^{45}$ The thousands of Jews forced to move into the ghetto from other parts of Warsaw could bring only a few belongings. The remainder, and all business assets as well, were appropriated by the conquerors without compensation. Of the tens of thousands of Jews who were moved into Warsaw from outlying towns, the vast majority arrived almost destitute. Those who had the means and the opportunity brought whatever valuables they were able to preserve through body searches by various guards en route; these could be sold to help support the family. But most Jews had little or nothing.

The Nazis prohibited the importation into the ghetto of food other than the approved and grossly insufficient rations. Thus smuggling became a major occupation for many, even though it was an activity repeatedly proven to have lethal consequences. These realities sent prices soaring.

Except for those on work details initiated by the Germans, all Jews eventually were restricted to the ghetto, on pain of death. ${ }^{46}$ There, the potential employers were, with

${ }^{41}$ HCMU/OHA, interview of Karolina Borman, HCM 3-84, 29 March 1984, p. 36-7.

42 Stanislaw Adler, In the Warsaw ghetto, 1940-1943: an account of a witness, Jerusalem, Yad Vashem, 1982 , p. 123.

${ }^{43}$ The zloty was, and is, the unit of currency in Poland. In 1939, five zlotys were the equivalent of approximately \$1 (US); by 1943,800 zlotys were equal to \$1. See Sybil Milton (trans. and ed.), The Stroop report: the Jewish quarter of Warsaw is no more!, London, Secker \& Warburg, 1980, n.32.

${ }^{44}$ Donat, op. cit., note 24 above, p. 7.

45 Jan Kapczan, "Account of the ways of financial management in the Jewish communities in the occupied territory during the war', in Kermish, op. cit., note 17 above, p. 296.

${ }^{46}$ Before the end of 1941 , eight Jews caught outside the ghetto without permission were executed by the Nazis. According to Dr Izrael Milejkowski, "his superior, Dr Wilhelm Hagen, was directly responsible for the execution. It was the only way, Hagen claimed, to stop Jews from spreading typhus outside the Ghetto." (See Donat, op. cit., note 24 above, p. 47.) 
a few notable exceptions, their fellow Jews. Though the population probably averaged, over the period from 1940 through July 1942, about 450,000 (deaths were more than balanced by periodic influxes of refugees from other Jewish communities in occupied Europe), there were only so many jobs that needed to be done, and there were fewer and fewer institutions and factories capable of paying others for their work. Moreover, by German edict, Jews received only 80 per cent of the wages paid for the same job to "aryan" workers, and all their benefits, including limitation of working hours, overtime pay, and vacations, were cancelled. ${ }^{47}$ Shops had trouble getting materials, human needs became increasingly pitched at the level of survival, and prices continued to rise.

Some Jews-particularly large-scale smugglers-became rich temporarily, and some, rich before the war, remained better off than most. The first group seems to have done essentially nothing by way of charity or social aid, and the second group did less than they might have, if contemporary writers were accurate in their criticisms. ${ }^{48}$ Rabbi Yitzhak Katz, in January 1942, charged that too few Jews were acquitting themselves "of the elementary duty of commiseration. In the streets we see people dying of hunger, starving, stumbling and falling in the street, without anyone showing compassion for them ...".49 By November 1941, a survey suggested that 80 per cent of the 100,000 children then in the ghetto required public aid and care. ${ }^{50}$ Yet the means of funding such care were shrinking daily.

Inevitably, both teachers and students in the medical school were affected by these conditions. It was decided that the students must pay for their education, just as everyone else paid for goods or services. The monthly fee was set at 60 zlotys, though about a quarter paid only $\mathbf{4 0} \mathrm{zl}$ and a number paid nothing, receiving a "bursary" from the Judenrat. 51 Since the school functioned only in the evenings, this may have been less prejudicial economically than it seems, because students worked at other jobs, if they could get them, in the daytime. ${ }^{52}$ From this income, the teachers in the school received salaries of between 200 and $300 \mathrm{zl}$ per month. ${ }^{53}$ In May 1942, a writer estimated that feeding a family required $1,000 \mathrm{zl}$ per month. ${ }^{54}$

\section{MEDICAL EDUCATION}

It was in this context that the Germans approved the creation of Sanitary Courses

\footnotetext{
${ }^{47} \mathrm{~N}$. Rosen, 'The problem of work in the Jewish quarter-July 1942', in Kermish, op. cit., note 17 above, pp. 251-2.

${ }^{48}$ See, for example, the scathing letter from A. M. Rogowy, 5 September 1941, ibid., pp. 317ff.; also [anon.], 'Economic life in the ghetto as of its establishment in November 1940', ibid., p. 537.

${ }^{49}$ Rabbi Itzhak Katz, 'Things I intended to say', ibid., p. 356.

50 Natan Koninski, 'The profile of the Jewish child', ibid., p. 390.

51 One woman now living in the USA, whose name has not been revealed to me, reportedly remains bitter to this day because she believes she was prevented from attending school because she lacked the necessary tuition money. Borman, HCM 23-82, p. 7.

52 See the Appendix.

53 These figures all are taken from [Stanislaw Rozycki?], 'The school system', in Kermish, op. cit., note 17 above, p. 514. According to Rudowski and Zablotniak, the students paid $200 \mathrm{zl}$ tuition and teachers earned up to $10 \mathrm{zl}$ for an hour's lecture, though these figures may refer to the Warsaw school outside the ghetto, the so-called Zaorski school; see Rudowski, op. cit., note 18 above, p. 242-3.

54 [Rozycki?], 'The school system', in Kermish, op. cit., note 17 above, p. 511.
} 


\section{A medical school in the Warsaw ghetto}

for Fighting Epidemics. Vocational courses of several kinds were first approved in principle in August $1940 .{ }^{55}$ However, it appears that the proposal to hold medical vocational courses was not implemented until April 1941, and the opening lecture was given on 11 May $1941 .^{56}$ The organizer was Docent Juliusz Zweibaum, formerly of the Warsaw University medical school. Although some authors have given Hirszfeld the credit, ${ }^{57}$ the evidence of documentation and of surviving faculty and students makes it clear that Zweibaum was indeed the originator. He planned a school to provide basic medical education; later, when Dr Ludwik Hirszfeld became active in the ghetto, he undertook the organization of the Superior Course, for fourth- and fifth year studies. ${ }^{58}$

The creators of the clandestine medical school had one unanticipated advantage in dealing with the Nazis. The Germans seem to have been genuinely terrified of epidemic diseases. Though their claim that the Jews were especially susceptible to typhus, used as an excuse for quarantining them within the ghetto, was false, it is probable that many Germans believed their own propaganda. ${ }^{59}$ This fear may have been influential in obtaining approval for the courses "to combat epidemics" at a time when little other education was permitted. Moreover, the same fear kept the Nazis away from the school itself. A teacher there has recalled that they were almost never inspected, though surprise police inspections were routine elsewhere in the ghetto; it was as if the authorities thought that teaching about epidemic diseases might generate the diseases in the classrooms. ${ }^{60}$ Their failure to monitor the courses is doubly surprising because the main building used for teaching actually was outside the ghetto walls (see map), a structure that had been taken over as the Arbeitsamt or Labour Bureau. This structure was a former secondary school. To get to the school, the students had actually to leave the ghetto, passing the inspection of the guards at the wacha or inspection point; these guards usually included two German soldiers, two Polish policemen (known as the "Blues" because of the colour of their uniforms), and two members of the Ordnungsdienst or Jewish Order Service, internal police created by the Judenrat. ${ }^{61}$

\footnotetext{
${ }^{55}$ Hilberg et al., op. cit., note 14 above, p. 186, entry for 18 August 1940.

56 Ibid., p. 233, entry for 11 May 1941.

57 Gutman, for example, speaks of "a course in medicine by Professor Hirszfeld geared to the level of a professional school of medicine ...”. Op. cit., note 11 above, p. 105. This error probably reflects the remarkable prestige of Hirszfeld, who most certainly was an important figure in the school. Similarly, in Bernard Goldstein, Die Sterne sind Zeugen: der Untergang der polnischen Juden, Munich, Deutscher Taschenbuch, 1965 , p. 79, the only name cited in connection with the school (Die Sanitäterkurse) was that of Hirszfeld. Hirszfeld himself gives credit to Zweibaum, who "obtained a permit to organize a course for the sanitary personnel. The fact was that this was a clandestine first year in medical study." (Hirszfeld, op. cit., note 30 above, p. 206.)

${ }^{58}$ HCMU/OHA, interview of Dr Marek Balin, 16 May 1983, HCM 7-83, p. 11 ; Hirszfeld, op. cit., note 30 above, p. 209.

59 Browning, op. cit., note 12 above, p. 347-8.

${ }^{60}$ HCMU/OHA, interview of Dr Ludwik Stabholz, HCM 5-87, 11 June 1987, p. 29.

${ }^{61}$ On the Ordnungsdienst see Gutman, op. cit., note 11 above, pp. 85-90. Several of the ex-students interviewed have commented on how worrisome it was to have to leave the ghetto each day and travel the few feet from the ghetto gate on Leszno to the school. Although the guards of course knew of the school, they could be arbitrary in allowing students through. In at least one instance, a woman student was forced into the guards' quarters and raped. Sadly, but realistically, the teacher urged the students to ignore her cries and try to work. (See Borman, HCM 23-82, p. 13; also HCMU/OHA, interview of Irena Bakowska, 1 Feb. 1982, HCM 3-83, pp. 25-6.)
} 


\section{Charles G. Roland}

The Germans visualized a programme of a few weeks or months that would produce technicians capable of applying anti-epidemic techniques. The medical teachers used the approved courses as a front for clandestine medical education from May 1941 until July 1942.

The ghetto school considered itself a division of the Warsaw University and, so long as this was possible, there was both consultative and administrative co-operation; student records were conveyed to the faculty offices outside the ghetto and, for a while, some lecturers were exchanged. ${ }^{62}$ Nevertheless, as time went on the ghetto became more and more isolated and these contacts could not be maintained. To ordinary Poles outside the ghetto, the existence of anything as ambitious as a Jewish medical school seemed unlikely. ${ }^{63}$

\section{The primary course}

This term designated the first two years of the traditional Polish medical education, during which the students were taught the basic medical sciences. The formal teaching of the pre-clinical subjects in the underground school was carried out in a large building at the corner of Leszno and Zelazna Streets. ${ }^{64}$ It had been a public school before the war, and housed many other operations during the war years. The students remember large rooms on an upper floor, bright in the daylight hours. ${ }^{65}$ Instruction p. 21 .

${ }^{62}$ Borman, HCM 23-82, p. 8; HCMU/OHA, interview of Tadeusz Stabholz, 4 Dec. 1982, HCM 26-82,

${ }^{63}$ One Christian Polish interviewee, herself a medical student in Warsaw during the war, expressed doubts in 1985 that such a school could have existed in the ghetto, because conditions were known to be so hopeless there; HCMU/OHA, interview of Dr Janina Zaborowska, 12 Sept. 1985, HCM 76-86, p. 13.

${ }^{64}$ HCMU/OHA, interview of Ludwik Stabholz, 11 June 1987, HCM 5-87, p. 12; HCMU/OHA, interview of Halina Berg, 14 Sept. 1984, HCM 6-84, p. 12.

${ }^{65}$ Pernal, HCM 4-87, p. 12; L. Stabholz, HCM 5-87, p. 29; Bakowska, HCM 3-83, p. 24.

The area of the Warsaw ghetto, with the boundary as of 22 July 1942, the day massive deportations to Treblinka began. The ghetto changed shape several times between its creation in November 1940 and its final destruction in May 1943. The present map indicates its limits during much of the time the underground medical school existed.

Only a few of the sites particularly relevant to the school are identified. 1. Umschlagplatz. 2. Czyste Hospital, Stawki 6-8 (infectious diseases, internal medicine). 3. Czyste Hospital, Stawki 21. 9. Czyste Hospital, Gesia St., September 1942-January 1943: last hospital functioning in the ghetto. 24. Arbeitsamt (labour office); also site of lecture rooms, underground medical school, April 1941-July 1942. 25. Czyste Hospital, Leszno 109 (typhus hospital?). 29. Czyste Hospital, Leszno 1 (surgery); site of former Polish State Tobacco and Alcohol Monopoly; Marek Balin, Karolina Borman, Millie Eisen, Henry Fenigstein, and Tadeusz Stabholz worked here. 30. Czyste Hospital, Tlomackie 5 (obstetrics and gynaecology). 38. Czyste Hospital, Elektoralna 12 (in wing of bombed-out Hospital of the Holy Ghost; pharmacy, disinfection, sterilization, etc.). 44. Berson and Baumann Hospital, Sliska 52. 45. Janusz Korczak orphanage, Sienna 16 and Sliska 9.

This map is derived from numerous sources, including several of the personal interviews, and the following books: Joseph Ziemian, Gevulot Geto Varsha Veshinuyehem [The Borders of the Warsaw Ghetto] (Jerusalem: Yad Vashem, 1971); Trunk, op. cit., note 8 above; Gutman, op. cit., note 11 above; Hilberg et al. (eds.), op. cit., note 14 above; Kermish (ed.), op. cit., note 17 above; Falstein (ed.), op. cit., note 20 above; Sloan (ed.), op. cit., note 26 above; Tushnet, op. cit., note 31 above; Adler, op. cit., note 42 above. 


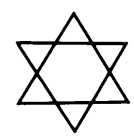

THE WARSAW GHETTO 1940-1942

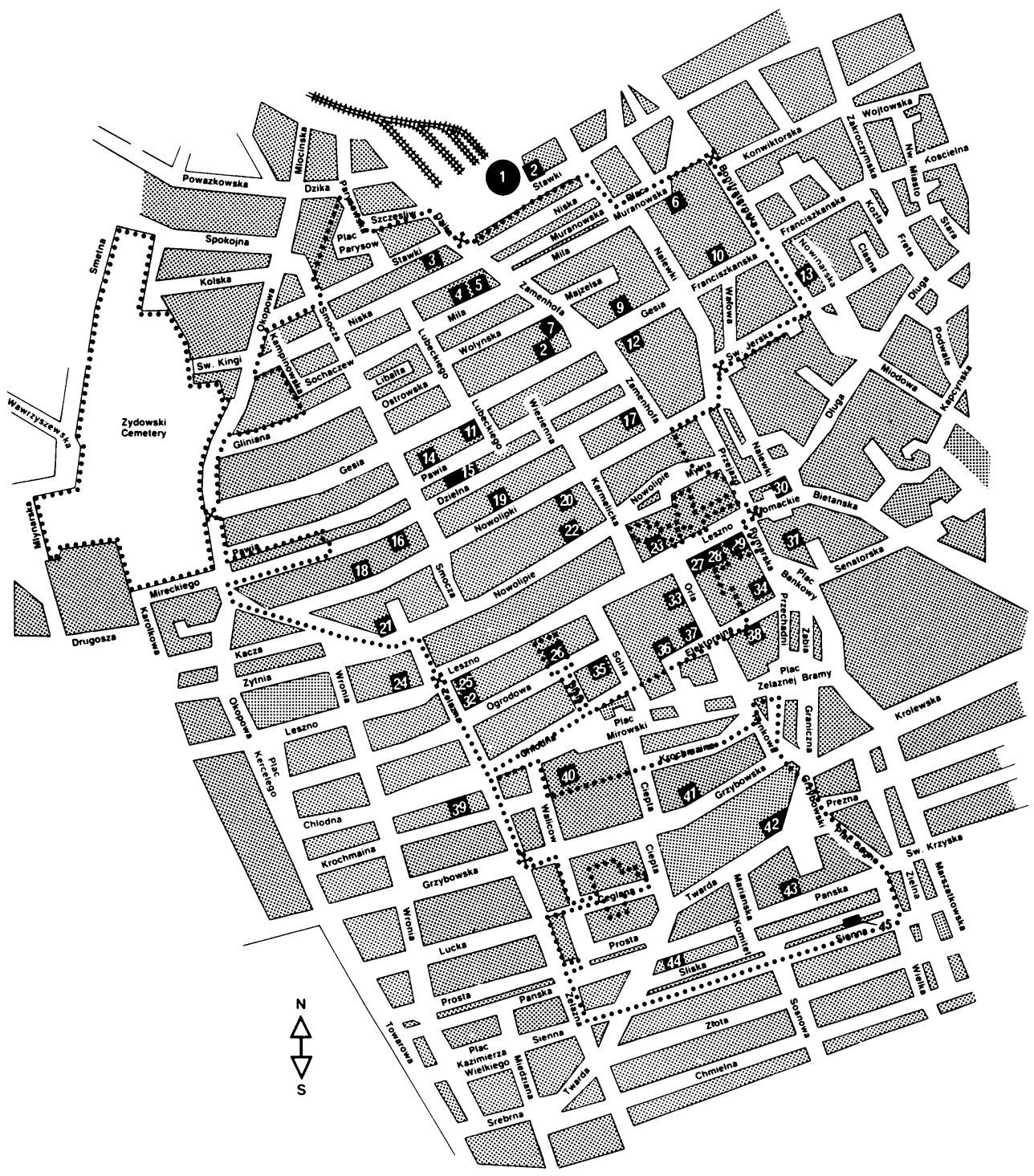




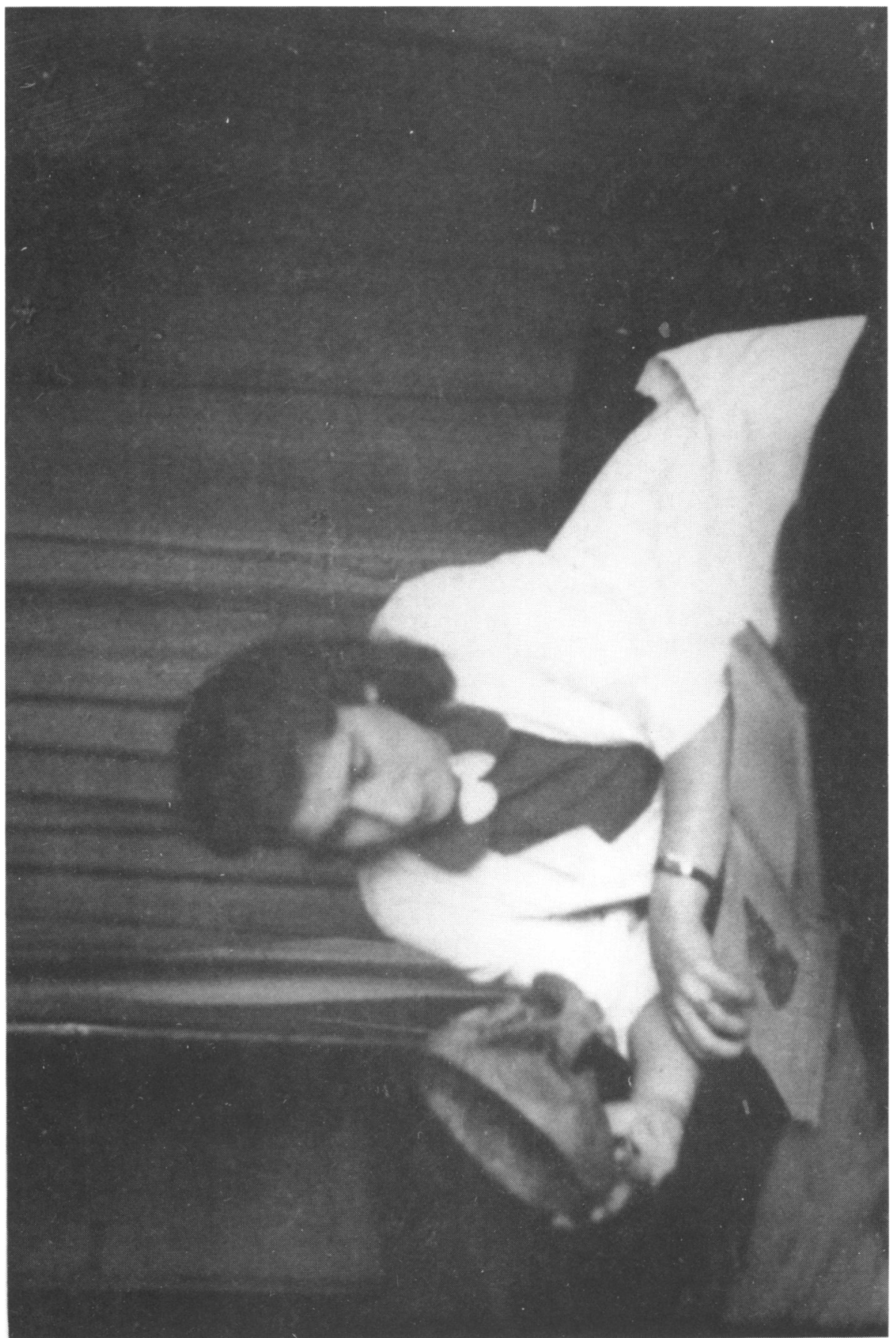

Medical student studying anatomy in the Warsaw ghetto, c. 1941. (Courtesy of Dr B. J. Wygodzka, Poland.) 
was largely by lectures; some laboratory space was available, though the facilities were primitive. ${ }^{66}$ The students sat on benches, as in classrooms everywhere. ${ }^{67}$

Lectures that were described to the Germans as basic outlines of anatomy, hygiene, and public health were, in fact, medical lectures designed for medical students. ${ }^{68}$ Books were in scant supply and had to be passed from one student to the next on a strict rota. ${ }^{69}$ Ironically, despite the high mortality rate in the ghetto, anatomical specimens were scarce. Skulls had to be smuggled into the school, and histological and pathological slides were passed from student to student so that all could examine them. ${ }^{70}$ Bodies were readily available but preservatives were not. ${ }^{71}$ Thus much of the practical teaching of anatomy took place in hospital morgues; ${ }^{72}$ one student remembers vividly how a cadaver's neck was kept stretched by placing a brick under it, ${ }^{73}$ and another was struck by the emaciated appearance of the bodies and the fact that the male sex organs were so much less conspicuous than she had imagined-not having had a previous opportunity to make such observations. ${ }^{74} \mathrm{~A}$ few fortunate students had access to skulls and other teaching material because their parents were physicians or dentists (see photograph). ${ }^{75}$

The faculty surreptitiously obtained demonstration tables and histological preparations through colleagues at Warsaw University, ${ }^{76}$ particularly Dr Orlowski and Konopacka, ${ }^{77}$ and Dr Edward Loth. The last-named, notoriously anti-Semitic before

${ }^{66}$ Borman, HCM 23-82, p. 15; Berg, HCM 6-84, p. 43-4; L. Stabholz, HCM 5-87, p. 14.

67 Balin, HCM 7-83, p. 16.

68 The Jews had already proven their capability for fooling the Germans in this way. As early as 1935, in Germany, when Jews were banned from attending universities, a Hochschule für die Wissenschaft des Judentums was secretly transformed into a Jewish university; the Nazis were told that it was a religious school, which at that time they were prepared to tolerate: see Dawidowicz, op. cit., note 8 above, p. 186.

${ }^{69}$ Several students remember doing this (Pernal, HCM 4-87, p. 23; Borman, HCM 23-82, p. 12). However, others recall no shortage of books (see Berg, HCM 6-84, p. 43). Balin had the good fortune to study with students from a very well-to-do family who had apparently unlimited books and equipment, a situation that certainly was atypical (Balin, HCM 7-83, p. 14). Only three texts used in the ghetto are identifiable with certainty. Dr Ludwik Stabholz owns two anatomical texts that were given him by his professor at Warsaw University, Dr Edward Loth, and which he used in teaching students in the underground school. They are: Adam Bochenek, Anatomja Czlowieka: Podrecznik dla Sluchaczow Szkol Wyzszych i lekarzy [Human anatomy: a textbook for students of higher schools and physicians], vols. 2-3, Cracow, Nakladem Polskiej Academji Umiejetnosci, 1921, 1928; and Zygmunt Messing, Krotki Zarys: Anatomji I Fizjolocji Osrodkowego Ukladu Nerwowego [Synopsis of anatomy and physiology of the central nervous system], University of Warsaw, 1922-23, Balin, Borman, and Tadeusz Stabholz remember using the Sobotta atlas (see Borman, HCM 23-82, p. 11; T. Stabholz, HCM 26-82, p. 18): Joh. Sobotta, Atlas der deskriptiven Anatomie des Menschen, 3 vol., Munich and Berlin, J. F. Lehmann, 1941; Dr Borman's copy is in the author's possession.

70 Borman, HCM 23-82, p. 15.

${ }^{71}$ HCMU/OHA, interview of Dr Henry Fenigstein, 28 June 1982, HCM 17-82, p. 4.

72 Berg, HCM 6-84, p. 14; HCMU/OHA, interview of Dr Henry Fenigstein, 21 Jan. 1982, HCM 3-82, p. 7; L. Stabholz, HCM 5-87, p. 9.

73 Bakowska, HCM 3-83, p. 24.

74 Borman, HCM 23-82, p. 11; Bakowska, HCM 3-83, p. 22.

75 Bakowska, HCM 3-83, p. 23; Berg, HCM 6-84, p. 44.

76 Juliusz Zweibaum, 'Kurs przysposobienia sanitarnego do walki z epidimiami w getcie Warszawskim w latach, 1940-1942', ['Courses of sanitary training to fight epidemics in the Warsaw ghetto, 1940-1942'], Archwm Hist. Med., 1958, 21: 355-6.

${ }^{77}$ Edwarda Mark, 'Konspiracyjne wyzsze szkoly medyczne ['Conspiracy to provide higher medical education']', Sluzba Zdrowia [Health Services, a weekly periodical], 1962, p. 3. 


\section{Charles G. Roland}

the war, carried pathological anatomy specimens preserved in formaldehyde, into the ghetto for his former student, Dr Stabholz, to use in demonstrating normal anatomy. ${ }^{78}$

The clandestine nature of the teaching made subterfuge routine. One student remembers finishing her high school education by meeting with a teacher and three or four fellow students alternately in each student's home, ready to simulate an ordinary social gathering should Germans arrive unexpectedly. ${ }^{79}$ Such a degree of secrecy was unnecessary in the medical school because of its quasi-legal status, but Tadeusz Stabholz recalls that lectures would begin as simple descriptions of epidemic diseases-the "sanitary courses" cover-and then quickly shift to the actual subject under consideration: physiology, pathology, or biochemistry. A roll was kept of those present for the information of Dr Zweibaum's office, but this potentially incriminating document vanished quickly once the students had signed in. ${ }^{80}$ Moreover, pamphlets and books relating to epidemics were left scattered on a table in the lecture room, and disinfectant spread around, making the room redolent of anti-epidemic measures. ${ }^{81}$

In the evenings, particularly in winter, the rooms were lit by carbide lamps, remembered as being helpful but smelly. ${ }^{82}$ The hallways and stair-wells were especially cold and dark. ${ }^{83}$ The rooms were inadequately heated, though this was even more of a problem when attempting to study at home, at night. There, work was difficult and the experience worrisome; if you studied with another student, the visitor had to stay overnight because the curfew was enforced strictly. ${ }^{84}$ Study was often disturbed by the sound of an automobile approaching through the dark streets-always alarming because only the Gestapo drove automobiles within the ghetto. ${ }^{85}$

One major difficulty connected with the school was the danger involved in reaching it. The school building was actually outside the ghetto walls, though only by a few metres. Consequently, each student had to pass the scrutiny of German, Polish, and Jewish police guards. In addition to the regular documents, required of all the ghetto's inhabitants, a student card was apparently also used for identification. ${ }^{86}$ With the constant potential for violence, the students were apprehensive and fearful. ${ }^{87}$ This corner was a hazard for all inhabitants of the ghetto, not just the medical students. One noted dryly:

${ }^{78}$ L. Stabholz, HCM 5-87, pp. 10-11.

${ }^{79}$ Bakowska, HCM 3-83, p. 17.

${ }^{80}$ T. Stabholz, HCM 26-82, pp. 12, 14.

${ }^{81}$ T. Stabholz, HCM 26-82, p. 14.

${ }^{82}$ T. Stabholz, HCM 26-82, pp. 18, 20; Bakowska, in Borman, HCM 23-82, p. 29; Fenigstein, HCM $17-82$, p. 4.

${ }^{83}$ Borman, HCM 23-82, p. 14; Bakowska, HCM 3-83, p. 22.

${ }^{84}$ HCMU/OHA, interview of B. J. Wygodzka, 8 Jan. 1988, HCM 1-88, p. 16.

${ }^{85}$ Bakowska, HCM 3-83, p. 26-7; Borman, HCM 23-82, p. 9; Borman, HCM 3-84, pp. 18, 44. An anonymous historian in the ghetto has outlined the significance of hearing an automobile: "Every night people were killed. The procedure was established. A car would stop in front of the house. Steps would reverberate. Someone would leave the flat under escort. A shot would then be fired in the gateway or on the nearest street-corner. At night, the ears were kept cocked in fear lest the car passing in the street should stop. Knocking on the front foor of a building made the hearts of all its inhabitants thump in the instinctive, mortal fear of all living creatures": 'The last stage of resettlement is death', in Kermish, op. cit., note 17 above, p. 706.

${ }^{86}$ Berg, HCM 6-84, p. 10.

${ }^{87}$ Bakowska, HCM 3-83, p. 25-6; Borman, HCM 23-82. 
Another bit of amusement for the gendarmes was to stop people at the corner of Zelazna and Leszno. People had to pass through there even though it was close to an outpost of gendarmes . . there were frenzied beatings with any object at hand. ${ }^{88}$

One student found it increasingly difficult to force herself to attend the sessions. ${ }^{89}$ Not surprisingly, perhaps, female students recall this more often than the male; hearing the cries of fellow-students being raped in the guardhouse would have made the risk crystal clear. ${ }^{90}$ However, male students were frequently beaten on their way to classes. ${ }^{91}$ Because the school building was outside the ghetto, some of the more "aryan"-looking male students removed their armbands and explored Warsaw outside the ghetto. Not only were they in great danger, but they would have compromised the school, had they been caught. ${ }^{92}$ The risk cannot be overestimated; Hirszfeld remembers hearing shouting from the streets during classes: "the wacha [guard] down on the street was killing a Jew.",93

In addition to their formal classes in the evenings, the pre-clinical students had other opportunities to learn. During the daytime, students were welcomed into the ghetto's hospitals and clinics, where they could find not only unlimited ways to be of service, but also teachers avid to teach. Only those who did not need to work could take advantage of this opportunity but there were many whose parents remained able to support them, at least for a time. Fenigstein, working as a pathologist in Czyste Hospital, combined informal lectures with practical demonstrations, after which the students dissected the body part being studied; much of this was done during the day, in regular hospital hours, and provided extra instruction for those students able to allot the time to it. ${ }^{94}$ In this way he supplemented the more formal lectures, followed by the study of preparats (formalin-preserved pathological specimens used here for teaching normal anatomy), which was the procedure followed by Stabholz and his colleagues in the evening sessions.

\section{The superior course}

The so-called "superior course" consisted of the final four, clinical, years of medical education in the Polish system at the time. Clinical teaching was carried out in the hospitals and clinics of the ghetto. Like everything else in that compressed, strangling world, the hospital system of the Warsaw ghetto was complex, patched-together, inefficient, and overstrained. Before the war, the Czyste Hospital had been a superior institution, well equipped and staffed, with 1,490 beds, 147 physicians, 119 nurses, and six pharmacists. ${ }^{95}$ Its clientele was by no means exclusively Jewish, although the staff was, since Jews could rarely obtain teaching posts in non-Jewish hospitals.

${ }^{88}$ Adler, op. cit., note 42 above, p. 115.

${ }^{89}$ Borman, HCM 23-82, p. 14.

90 Borman, HCM 23-82, pp. 13, 31; Bakowska, HCM 3-83, pp. 23, 25-6.

91 "Often the German soldiers beat the male students if they thought they looked too Semitic, so that on later days we would see our colleagues attending with bandaged heads . . .": Alicja Zawadzka-Wetz, Refleksje Pewnego Zycia, Paris, Instytut Literacki, 1967, p. 23. Zawadzka-Wetz was herself a student in the underground medical school.

92 Borman was quite worried that this would happen; HCM 23-82.

93 Hirszfeld, op. cit., note 30 above, p. 207.

94 Fenigstein, HCM 17-82, pp. 5-7.

95 Apenszlak, op. cit., note 7 above, p. 38. 


\section{Charles G. Roland}

It was not located within what became the ghetto; thus, after the ghetto's bounds were defined, the hospital was forced to abandon its buildings and much of its equipment. Marek Balin, a medical student in Paris before the war, was in Warsaw when the fighting began and, along with more than a dozen other medical students in similar circumstances, he ended up as a member of the in-house staff of Czyste Hospital. ${ }^{96} \mathrm{He}$ thus became a part of the caravan that made the enforced move into the ghetto; he and his colleagues smuggled as much equipment as possible since the Nazis had decreed that only easily portable materials could be taken from the original site. ${ }^{97}$

For the rest of the hospital's existence it occupied portions of several buildings, none of them designed as hospitals and none of them adequate. ${ }^{98}$ These were located on many streets, including Leszno 1, Tlomackie 5, Stawki 6-8, Stawki 21, Zelazna 80, Elektoralna 12, and Leszno 109 (see map). The site at Stawki 6-8 was, formally, the final one for the Czyste Hospital; it was at the edge of the Umschlagplatz, from which the bulk of the population was transported to Treblinka and other concentration camps. A children's hospital was located on Sliska Street ${ }^{99}$ The Czyste Hospital was the main arena, but student work in anatomy, and in all laboratory and clinical subjects, was also carried out in numerous other makeshift hospitals and clinics in the ghetto.

Within the hospitals, conditions were deplorable. Doctors, nurses, and other staff were in short supply to begin with, and the staffing situation became almost impossible as individuals vanished without trace from one day to the next, caught up in the Nazi destructive process in one way or another. "We would have one day a lecture at 1 o'clock and the teacher wouldn't show up. A few days later we would find out that he was killed. Then they found a substitute. It was rather primitive." 100 The event could be totally capricious. Katznelson recalled passing a well-dressed man in the ghetto one day and, shortly afterwards, hearing a shot. He turned back and learned that the Germans had kicked the man and, as he turned towards them, they shot him; he was a Jewish doctor. ${ }^{101}$ Sometimes people disappeared because, when labourers were needed, the Germans rounded up as many people as they needed off the street, without regard for occupation or the possession of passes. Eugenia Pernal was taken to the Umschlagplatz despite being in her nursing uniform and carrying the correct papers. She managed to extricate herself. ${ }^{102}$

${ }^{96}$ Balin, HCM 7-83, p. 7.

${ }_{97}$ Balin, HCM 7-83, p. 8; T. Stabholz, HCM 26-82, p. 11.

98 The main hospital at Leszno 1 , which could contain about 200 patients under reasonable conditions, held 600 in 1942. YVA 03/441, testimony of Dr Marek Balin, 'Selekcja w szpitalu', p. 93.

${ }^{99}$ These addresses are derived from several sources, most particularly Falstein, op. cit., note 20 above, especially pp. 113-17, 197-9, and 227-30. See also Henry Fenigstein, The Warsaw Jewish hospital during the Nazi regime [title trans. from Yiddish], Frankfurt, Joh. Wagner \& Sohne, 1948. Exactly what hospital activities were carried out at each location changed from time to time and is difficult to determine; moreover, some sections changed locations. Undoubtedly some have not been mentioned here because the archival material is incomplete; this general problem invests all studies for this time and place.

${ }^{100}$ Balin commented on the disappearance, day to day and without explanation, both of fellow students and of teachers. Balin, HCM 7-83, pp. 26 and 34.

101 Yitzhak Katznelson, Vittel Diary, trans. Myer Cohen, Israel, Beit Lohamei Hagettaot \& Hakibbutz Hameuchad, 1972, p. 98.

102 Pernal, HCM 4-87, pp. 16-18. The Umschlagplatz was a railway freight-loading area just at the edge of the ghetto; from here, trains left regularly for many weeks from 22 July 1942, taking the ghetto inhabitants to their deaths at Treblinka and other camps. 


\section{A medical school in the Warsaw ghetto}

Supplies were almost non-existent. Wards were so crowded that two patients per bed was routine, and various epidemic diseases ran unchecked through wards of every kind, surgical as well as medical; one survivor wrote that often " 3 to 4 people were thrown into the same bed like dirty rags, typhoid cases and noninfectious ones stayed together for days". ${ }^{103}$ Pernal worked as a nurse in the Berson-Bauman Children's Hospital in 1941 and 1942. There, what sheets they had were torn to make diapers, hunger was so acute that the older children stole from the younger ones, and children arrived in the hospital literally seething with lice and other parasites. Dysentery and bed sores were among the commoner clinical problems. ${ }^{104}$

The faculty attempted to teach clinical medicine in this environment. The students' activities were largely what one would expect in any medical school. They learned to give injections and to write prescriptions; occasional lectures were attended during the daytime and the students did clerkships in rotation through the typical medical and surgical services. ${ }^{105}$ Not surprisingly, students often found themselves pressed into service as orderlies or as nurses. ${ }^{106}$ One man, previously a medical student outside Poland, who arrived in Warsaw in March 1942, found himself working in the desperately busy pathology department with Dr Fenigstein. ${ }^{107}$

But if the names of the clinical services were typical of medical education elsewhere, the conditions were not. The survivors relate experiences that put this school quite outside customary bounds. Balin served in the hospital at the Umschlagplatz where, briefly until he ran away, he was forced by the Nazis to select, from among the patients-his patients-, those for "transportation" (the euphemism for extermination at Treblinka). ${ }^{108}$ Pernal has described the wounds swarming with maggots in her paediatric patients, ${ }^{109}$ and she had the appalling experience, one day, of actually observing a mother gnawing on her dead child. ${ }^{110}$ Eisen saw a boy kicked to death on the street by several German soldiers, ${ }^{111}$ and late in the existence of the ghetto, in the very last hospital, on Gesia Street, ${ }^{112}$ many of her patients threw themselves off the roof of the building to their deaths, when the German lorries arrived to take them to the Umschlagplatz. ${ }^{113}$ Borman found a dying woman in the street who, just as she expired, gave birth to a living baby. ${ }^{114}$

Of course, the ghetto's whole social structure was twisted, particularly in its last two years. Bakowska, both of whose parents were dentists, remembers patients

${ }^{103}$ Evidence of Dr Emil Apfelbaum, op. cit., note 38 above, p. 3.

104 Pernal, HCM 4-87, pp. 27-9.

${ }^{105}$ Balin, HCM 7-83, pp. 9, $12,26$.

106 T. Stabholz, HCM 26-82, p. 15.

${ }_{107}$ Frank Stiffel, The tale of the ring: a kaddish, Toronto and New York, Bantam Book, 1985, p. 56.

${ }^{108}$ Balin, HCM 7-83, p. 13.

109 Pernal, HCM 4-87, pp. $28-9$.

110 Pernal, HCM 4-87, p. 31; Czerniakow refers to a similar case, in February 1942, of a mother charged by the Jewish Order Service with cannibalism; purportedly she had eaten a portion of the buttock of her 12-year-old son, who had died the day before. (Hilberg et al., op. cit., note 14 above, p. 328.)

${ }^{111}$ HCMU/OHA, interview of Millie Eisen, 20 June 1985, HCM 58-85, p. 6.

112 A moving and detailed eyewitness account of the Czyste Hospital during its last months in the ghetto, particularly the period on Gesia Street, is contained in YVA 03/398 0-3/2-2, Sabina GurfinkielGlocerowa, 'Szpital na Czystem', ['The Czyste hospital'], 51 pp.

${ }^{113}$ Eisen, HCM 58-85, p. 19.

114 Borman, HCM 3-84, p. 39. 


\section{Charles G. Roland}

having gold inlays or caps removed so that they could sell the gold and buy food and shelter. ${ }^{115}$ Berg survived the war, at least partly because she had the good fortune to contract an arranged marriage; after 22 July 1942, single women without jobs were being transported to Treblinka, but married women had a chance to stay in the ghetto longer. She was married in name only, to a man older than her father; shortly after, her new husband was able to save her from the Umschlagplatz. ${ }^{116}$ Such arranged marriages were common, though the chances of either bride or groom surviving were negligible.

The medical students were regularly examined. The results were recorded and, it is believed, were communicated to the school outside the ghetto as long as this remained possible. Dr Stabholz gave only oral exams to his anatomy students. ${ }^{117}$ The survivors all remember undergoing oral exams, ${ }^{118}$ and there were written exams as well. These were taken seriously, unsuccessful candidates often weeping over their failure. ${ }^{119}$

No records exist of the names of the students, or even of their numbers. One estimate is that as many as 500 persons may have obtained some medical education during the 15 months the school existed. ${ }^{120}$ Borman thinks there may have been 250 in the first year alone, ${ }^{121}$ while Ludwik Stabholz remembers about 100 in a class. ${ }^{122}$ If this last figure can be multiplied by two, for each year that he taught anatomy in the Primary Course, that would come close to Borman's figure. Tadeusz Stabholz recalls groups of thirty or more in the clinical classes, though these figures would be more difficult to document since these students were located in a variety of hospitals and clinics. ${ }^{123}$ Few survived the deportations to Treblinka that began on 22 July 1942 . One estimate is that, after the war, about 50 students received certificates confirming their participation. ${ }^{124}$ Fortunately both for himself and for his students, Dr Zweibaum survived the war; because all records had been destroyed, he personally attested to the progress and accomplishments of several students and they were able to begin their studies with credit for the work already done. ${ }^{125}$ Borman believes that of the approximately 250 students in her own class, only about eight survived the war to resume medical studies in Poland, ${ }^{126}$ of course, others completed their education elsewhere. ${ }^{127}$

\section{THE MEDICAL FACULTY}

We are able to identify many of those who taught. Three of the most important people in the underground medical school were Dr Izrael Milejkowski, Docent Dr Juliusz

\footnotetext{
115 Bakowska, HCM 3-83, p. 29.

116 Berg, HCM 6-84, pp. 19 ff.

117 L. Stabholz, HCM 5-87, p. 15.

118 See, e.g., T. Stabholz, HCM 26-82, p. 18, and Balin, HCM 7-83, p. 12.

119 Berg, HCM 6-84, pp. 42-3.

120 This is the figure given in Zweibaum, op. cit., note 76 above, p. 356; also cited in Mark, op. cit., note 77 above.

121 Borman, HCM 23-82, pp. 5, 16.

122 L. Stabholz, HCM 5-87, p. 11.

123 T. Stabholz, HCM 26-82, p. 20.

124 Zweibaum, op. cit., note 76 above. Since Zweibaum was the originator of the school, his evidence in this regard should have weight.

125 Wygodzka, HCM 1-88, p. 13; Borman, HCM 23-82, pp. 26-7; Balin, HCM 7-83, p. 25.

126 Borman, HCM 23-82, p. 17.

127 Where, not surprisingly, no credit was given for the clandestine studies; see T. Stabholz, HCM 26-82, pp. 34-5.
} 


\section{A medical school in the Warsaw ghetto}

Zweibaum, and Professor Dr Ludwik Hirszfeld. Milejkowski was head of the department of health, one of the creations of the Judenrat when responsibility for the city enclosed within a city was thrust upon it. Zweibaum, before the war a teacher in the medical faculty of Warsaw University, was the titular head of the clandestine school. And Hirszfeld, a world-famous scientist who had been forced into the ghetto despite being baptized (the Nazis decreed that Jewishness was racial, not religious), became a teacher whose charisma and reputation did much for the credibility of the school.

Izrael Milejkowski (1887-1943) became, on 18 September 1939, head of the Health Division of the newly appointed Judenrat. ${ }^{128}$ He played a significant role in encouraging the creation of the medical school, but his chief contribution to the medical history of the ghetto was his promotion and support of the teams conducting research into starvation. ${ }^{129}$ On 18 January 1943, he was captured in the ghetto, with the remnants of a TOZ ${ }^{130}$ team, and taken to Treblinka. According to unverifiable reports, he committed suicide en route. ${ }^{131}$

Juliusz Zweibaum (1887-1959) was the person whose name is most closely associated with creating the school. It was Zweibaum who set up the technical courses that screened its real function. His area of personal research interest was histology. ${ }^{132}$ One of his students recalls his lectures on the subject, in which his enthusiasm was evident. ${ }^{133}$ Before the war he had been a docent in the Warsaw medical faculty after graduating in Bologna in 1913. ${ }^{134}$

Ludwik Hirszfeld (1884-1954) was by far the most scientifically prominent member of the faculty. ${ }^{135}$ His presence in the ghetto during its short, traumatic existence was both scientifically relevant and curiously ironic. Not only was he an authority on several of the diseases that affected the Jews of Warsaw, but he also had done highly original studies on the blood groups and their inheritance, a field that the German

128 Hilberg et al., op. cit., note 14 above, pp. 33, 75.

129 In October 1942, after most of the Jews had been transported to their deaths and all organized medical work had ceased, Milejkowski wrote an introduction to the hunger research studies. He concluded this, his last scientific record, with this defiant tribute: "A last few words to honor you, the Jewish doctors. What can I tell you, my beloved colleagues and companions in misery. You are a part of all of us. Slavery, hunger, deportation, those death figures in our ghetto were also your legacy. And you by your work could give the henchman the answer 'Non omnis moriar,' 'I shall not wholly die." Winick, op. cit., note 31 above, p. 5.

${ }^{130} \mathrm{TOZ}$ : an acronym for Towarzystwo Ochrony Zdrowia, a Jewish health organization founded in 1921 and extinct in 1943. It was particularly active in Warsaw and provided many services that the Judenrat would not or could not. See Falstein, op. cit., note 20 above, pp. 118-21.

131 See Joseph Tenenbaum, 'Nazi rule in Poland and the Jewish medical profession', ibid., p. 205.

132 Zawadzka-Wetz, op. cit., note 91 above, p. 23.

133 See, for example, his two articles on epithelial histology: 'Sur la survie de l'épithélium vibratile in vitro', and 'Analyse histophysiologique de l'épithélium vibatile en état de survie in vitro', C. r. Séanc. Soc. Biol., 1925, 93: 782-4, 785-7.

134 Falstein, op. cit., note 20 above, pp. 55-6.

135 Biographical sketch based on the following: H. Schadewaldt, 'Ludwig Hirszfeld', Dictionary of scientific biography, vol. 6, 1972, pp. 432-4; Falstein, op. cit., note 20 above, pp. 61-2; his biography, Historia Jednego Zycia, Warsaw, Instytut Wydawniczy Pax, 1967, in translation 'The story of one life', ed. Hanna Hirszfeldowna, trans. F. R. Camp and F. R. Ellis (unpublished typescript); interviews. Note his article on racial serological differences: Ludwik Hirschfeld [sic] and Hanka Hirschfeld, 'Serological differences between the blood of different races', Lancet, 1919, ii: 675-9. See also L. Hirschfeld, 'A new germ paratyphoid', ibid., i: 296-7. 
authorities cannibalized to create a "scientific" rationale for some of its ultimately lethal racial dogma. During World War I he served in Serbia, attempting to control epidemics of typhus and bacillary dysentery, and described the organism that came to be known as Salmonella hirszfeldi. In accordance with German interpretation, his baptism as a Catholic, performed many years before, was ignored and he was forced to enter the ghetto early in 1941. He escaped to the "aryan" side in 1943 and survived the war. ${ }^{136}$

Hirszfeld is remembered by the students from the clandestine school as a gifted teacher; he is one of the few teachers in the school for whom we can discern some flavour of personality from the skimpy records extant. Wygodzka found him an exciting lecturer, ${ }^{137}$ and Berg described him as "a poet of his science". ${ }^{138} \mathrm{He}$ told one class that they would be better to learn to be grave-diggers than physicians. ${ }^{139}$ Bakowska recalls clearly his statement, based on epidemiological principles, that they would all be dead inside the ghetto within five years, even if the Nazis did nothing more than keep them there. ${ }^{140}$

Other teachers included Jozef Stein (1904-43), Wladyslaw Sterling (1876-1943), Henryk Lewenfisz-Wojnarowski (1894-1956), ${ }^{141}$ Hilai Lachs, ${ }^{142}$ M. Centnerszwer, Henryk Stabholz (1882-1941), ${ }^{143}$ and the two interviewees, Ludwik Stabholz and Henry Fenigstein. The last is fondly remembered by several of the students as a friendly, out-going, encouraging young man. ${ }^{144}$ It is a measure of the times that The martyrdom of Jewish physicians in Poland lists fourteen men as those most heavily involved in the school. Of these fourteen, two survived the war. ${ }^{145}$

\section{MOTIVATION AND DEDICATION}

Perhaps the fundamental question to be asked about the clandestine school is, why? Why did faculty and students undertake this hazardous and apparently futile enterprise?

136 Falstein, op. cit., note 20 above, pp. 61-2, and Schadewaldt, op. cit., note 135 above. See also William H. Schneider, 'Chance and social setting in the application of the discovery of the blood groups', Bull. Hist. Med., 1983, 57: 545-62, especially pp. 555 ff. regarding Hirszfeld and his discoveries and their application to racial theories by the Nazis.

37 Wygodzka, HCM 1-88, p. 16.

138 Berg, HCM 6-84, p. 10.

139 Berg, HCM 6-84, p. 15.

140 Bakowska, HCM 3-83, p. 22; in his memoirs, Hirszfeld gave a statistical computation and concluded that the ghetto might have lasted eight years before it disappeared (Hirszfeld, op. cit., note 30 above, p. 230). With regard to his speaking ability, Hirszfeld recorded how impressed he had been by the theatrical lecturing style of his professor of philosophy in Berlin, Simmel: "later I endeavored to give my lectures the same plasticity of expression I found in Simmel." Ibid., p. 5. In describing the ghetto period, he wrote, "Never before did I speak with such lucidity and fire", (p. 207).

${ }^{141} \mathrm{He}$ also taught Wygodzka after the war and she remembers his annoying but unconscious habit, when on the telephone, of nodding or shaking his head, without speaking, in answer to questions; Wygodzka, HCM 1-88, p. 21.

142 Wygodzka recalls him as "a fine old man with white hair" who spoke in an unusually high-pitched voice; Wygodzka, HCM 1-88, p. 20.

${ }_{143}$ According to Tadeusz Stabholz, his father developed an infection after operating with inadequately sterilized instruments, and died in the ghetto about April 1941; T. Stabholz, HCM 26-82, p. 17.

144 For example, Borman, HCM 23-82, p. 10; Eisen, HCM 58-85, pp. 16-17; Pernal, HCM 4-87, p. 4.

145 Happily, the lists of the martyred are occasionally erroneous. Dr Henry Fenigstein is cited in Falstein, op. cit., note 20 above, as one who did not survive. He did, and meetings with him have been an important 


\section{A medical school in the Warsaw ghetto}

It may be useful to see motivation at two levels. Motivation may be general, driving all or most participants, and also personal, sometimes idiosyncratic. In the efforts of Dr Zweibaum and his colleagues to create a school, and in the aspirations of the students who enrolled, we can recognize motives no different from those associated with any other medical school. There existed an abundance of medical talent, a mass of patients for teaching purposes, a prospective student body lacking other intellectual activity, and a perceived need to replenish the ranks of the profession because of attrition both ordinary and extraordinary.

Most of those involved centred their rationale (no matter how self-delusively) on the attempt to lead a normal life. In the words of one student, "I felt that I must play normal. Everything is normal, otherwise I couldn't exist." ${ }^{146}$ These students expressed one common attitude: they were bored in the ghetto. Some were from families sufficiently well-off that they had no need to work. Others worked during the daytime, but they were young, bright, and ambitious. They needed more. Their anatomy teacher observed, "They wanted to learn. They had nothing to do .... It was not possible to go anywhere." 147 Borman noted, "We had the choice of total desperation, total demoralization, suicide (some did commit suicide), escapism (whiskey [vodka] or whatever they could find), but instead we started to study."148

The students who already had completed some years of study had also, of course, the pressure of an unfinished task driving them to complete their education. As one of them put it, "some of us were very anxious to learn. We had a lot of experience, a lot of exposure, and we wanted to know." 149

But these were by no means the sole motives. No ordinary medical school, this was a clandestine activity. Its forbidden nature was a factor in its participants' motivation as well as, more obviously, in the day-to-day operations of the school. Most of the survivors believe that the underground medical school should be seen as a form of rebellion, of refusal to accept full control of their lives by the Germans. This feeling was expressed in various ways: a "beautiful case of passive resistance", 150 "sort of a resistance not with machine guns or anything, but a different way", 151 "one was fighting the war in a special way", ${ }^{152}$ and the Germans can have my body, "but they will not have my soul". ${ }^{153}$ Chaim Kaplan defended even the frivolity of dancing within the ghetto because it could be a protest against the oppressors; ${ }^{154}$ how much stronger was the protest of clandestine higher education?

It is true that such statements were made forty years after the school died. But the opinions, and the manner in which they were given, have a ring of authenticity. Also,

source for this study. See interviews on 21 Jan. 1982 (HCM 3-82), 31 March 1982 (HCM 11-82), and 28 June 1982 (HCM 17-82).

146 Wygodzka, HCM 1-88, p. 12.

${ }^{147}$ L. Stabholz, HCM 5-87, p. 14.

148 Borman, HCM 3-84, p. 19.

149 Balin, HCM 7-83, p. 34.

150 Fenigstein, HCM 17-82, pp. 3-6.

151 T. Stabholz, HCM 26-82, p. 19.

152 Borman, HCM 23-82, p. 12.

153 Bakowska, HCM 3-83, p. 28.

154 Dawidowicz, op. cit., note 8 above, p. 213. 


\section{Charles G. Roland}

none of those interviewed suggested that this last, defiant, motive was their only one; and most expressed more prosaic reasons first.

As for the personal reasons, these varied widely. Fenigstein simply enjoyed teaching. When he heard that he might be able to be involved in the underground school, ". . . I grabbed this opportunity because it was not just a plain job, but it was something which was, for me, challenging, interesting, which I enjoyed." ${ }^{155}$ At the other extreme were students who used the classes as an escape from confinement in the home and from the dangers of the street, where one was subject to indiscriminate abuse. Jewish women were known to have been rounded up and used for sexual purposes by the Nazis. ${ }^{156}$ According to one of the students, some women attended the school at least partly because it offered a way of hiding for some portion of the day, in an environment dangerous enough but safer than the streets. ${ }^{157}$ Prosaically enough, some students attended simply because their parents wanted them to become physicians. ${ }^{158}$

In retrospect, it is easy to see how futile was the attempt to operate a medical school in the Warsaw ghetto. But the enterprise should not be written off as an empty gesture. Until the summer of 1942, perhaps the majority of the inhabitants of the ghetto believed that many of them would survive the war. They had no reason to think otherwise; although anti-Jewish sentiment had existed for centuries in central Europe, its most violent expression was the pogroms which, however frequent and grim, were isolated and sometimes spontaneous events that never rivalled the Holocaust in aims or results. Thus, the Jews of Warsaw assumed that this large-scale "pogrom" would, like the others, end, and life would return more-or-less to normal.

There is nothing particularly Jewish in this optimistic attitude, nor in its continuation in the face of contrary evidence. In warfare, we recognize the so-called "foxhole syndrome", in which each soldier is convinced that he will survive in his foxhole, though he knows that his compatriots nearby may not. Comparable instances abound in civil life and could be said to identify a basic psychological defence of humankind.

The underground medical school in the Warsaw ghetto was created for two not mutually-exclusive goals: to carry on normal life, and to flout German regulations. Similarly, students studied in the school in the hope of furthering their education, and to defy the Germans.

Thus both faculty and students had double goals that, although simultaneous, were nevertheless antithetical: to lead life "normally", and to combat the obvious abnormality in their lives. For the few survivors who continued their education after the war, it must be a source of some satisfaction, despite the attendant tragedies that distorted all their lives, to realize that they did succeed in fending off the awful pressures of their times. They lived on what was forbidden, and against all odds they have put their clandestine education to use. Milejkowski was right: Non omnis moriar. 159

155 Feningstein, HCM 17-82, p. 15.

156 Apenszlak, op. cit., note 7 above, pp. 28-9.

157 Balin, HCM 7-83, p. 28.

158 Bakowska, HCM 3-83, p. 18.

159 Horace, Odes, Book 3, 30. See note 129 above. 


\section{A medical school in the Warsaw ghetto}

\section{APPENDIX}

The following is a translation of possibly the sole original document to have survived the clandestine medical school in the Warsaw ghetto. It is an undated, typewritten sheet, the original belonging to Dr Ludwik Stabholz, in whose home I examined it, and who translated it. Copy in YVA 463/36-1.

\section{JEWISH COUNCIL IN WARSAW \\ BOARD OF HEALTH}

\section{Sanitary Course for Combating Epidemics}

The Sanitary Course for Combating Epidemics, approved by superior authority, takes, as its main aim, giving young people the scientific basis for understanding the essence and consequences of epidemics, and methods of combating them, by means of systematic lectures, theoretical and also practical.

The duration of the course will be 9 months. The following lectures will be held:

1. Anatomy

2. Histology

3. Histology of the nervous system

4. Biology

5. Chemistry

6. Physics

7. Physiology

8. Endocrinology \& vitamins

9. Physiologic chemistry

10. Histophysiology of sight

11. Histophysiology of hearing

12. Bacteriology \& serology

13. Infectious diseases

Individual lecturers in children's diseases

Social care during epidemics; Hygiene of individuals \& social hygiene

Disinfection; First aid in urgent accidents

Epidemics in history
Dr L. Stabholz

Doc. Dr J. Zweibaum

Dr J. Cunge

Dr P. Borensztejn

Prof. Dr H. Lachs

Prof. Dr M. Centnerszwer \& Prof. Dr H. Lachs

Dr H. Makower

Dr L. Jelenkiewicz

Dr M. Grynberg \& Dr A. Heller

Dr M. Karbowski

Doc. Dr H. Lewenfisz

Dr Br. Fejgin, Prof. Dr L. Hirszfeld, \& Dr R. Amzelowna

Dr M. Grosblat, Dr I. Bejles, \& Dr J. Stein

Doc. Dr H. Brokman, Dr J. Przedborski, Dr H. Hirszfeldowa, \& Doc. Dr Wl. Sterling

Dr M. Kon

Dr S. Szenicer

Dr S. Swieca

Lectures will be held six times a week, 3 hours daily from 5 to 8 in the evening. Demonstrations and practical works will be included in the lectures.

\section{ACKNOWLEDGEMENTS}

The author particularly acknowledges the contributions of the interviewees, many of whom participated at considerable mental cost to themselves. Several private donors assisted greatly in underwriting some of the travel needed to complete the research, particularly Dr Harold Segall and Mr Henry Kalinowice, both of Montreal. Translations from Polish were made by Ms Ewa Boniecka, Dr Marek Balin, and Dr Kris Cena. Dr W. Lewin, Kew Gardens, NY, Secretary-Treasurer of the Janusz Korczak Medical Society, has been supportive in many ways. Rabbi Bernard Baskin, Hamilton, Ontario, introduced me to Dr Henry Fenigstein, the key to this study. Dr Fenigstein, Professor Michael Kater, York University, Toronto, and Ms Connie Roland and Dr William Seidelman (both members of the Program in Medical History, McMaster University, Hamilton), all read various drafts of the paper and made many helpful suggestions. 